Thorax (1954), 9, 26.

\title{
MALIGNANT CELLS IN SEROUS EFFUSIONS COMPLICATING BRONCHIAL CARCINOMA
}

\author{
BY \\ ARTHUR I. SPRIGGS \\ From the Division of Laboratories, United Oxford Hospitals
}

(RECEIVED FOR PUbLICATION AUGUST 25, 1953)

The object of this paper is to report on the cytological features of tumour cells which have been identified by a smear technique in 21 pleural or peritoneal effusions complicating primary carcinoma of the lung.

There are already hundreds of cases reported in the literature of the past 80 years in which malignant cells have been found in pleural or peritoneal fluid, and every clinical pathologist is familiar with the large aggregations of bizarre vacuolated cells which are especially common in malignant ascites due to carcinoma of the ovary. This type of microscopical metastasis is particularly well shown in sections of centrifuged sediment, and the appearance of hollow acini leaves no doubt of the glandular origin of the tumour.

Malignant cells which are not of the adenocarcinoma type are far less frequently recognized, and it is a surprising fact that hardly any attempt has so far been made to classify the different types of cell shed into the serous cavities by different varieties of tumour. The reason for this gap in our knowledge is presumably the absence of any agreed system of classification even of the benign cells of effusions; it is over 50 years since the introduction by Widal and Ravaut (1900) of " cytodiagnosis," and there is still no atlas or illustrated monograph showing all the common types of cell encountered in effusions. Most textbooks of clinical pathology have only a few lines explaining that the identification of malignant cells is difficult and uncertain.

The introduction of Dudgeon's (Dudgeon and Wrigley, 1935) and Papanicolaou and Traut's (1943) wet-fixation techniques has resulted in only a slight advance in our knowledge of the cytology of serous fluids. Malignant cells in pleural and peritoneal fluid seldom show the hyperchromatism which is such a feature of squamous carcinoma cells in vaginal and sputum smears, and diagnosis has to depend on familiarity with all the types of cell which occur in the serous cavities.
The Romanowsky stains which are found satisfactory in the study of blood and bone marrow cells give equally good cytological detail in the cells of effusions, and classification of these cells using any other technique causes confusion to those who use orthodox haematological methods.

One of the commonest causes of malignant pleural effusion is anaplastic carcinoma of the lung of the small-celled variety, often known as "oat-cell carcinoma." Since this type of growth is particularly liable to dissemination over the pleura and pericardium, it is surprising to find that the metastasizing cells have hardly ever been described from the sediment of a serous effusion. Almost all published records of malignant cells in pleural effusions complicating primary carcinoma of the lung have referred to adenocarcinoma and not to the oat-cell variety.

A search of the older literature has not revealed any descriptions of oat-cells in pleural fluid. There are some records of malignant cells found by the Widal technique (air-dried Romanowsky-stained films), or by direct examination of wet films, from cases classified as "endothelioma" (Fraenkel, 1892 ; Schulze-Vellinghausen, 1900 ; Meslay and Lorrain, 1903 ; Bloch, 1905 ; Erben, 1906), as large round-cell sarcoma of the lung (Ravaut, 1901 ; Turton, 1905), or as primary carcinoma of the lung or bronchus (Quincke, 1882 ; Schwalbe, 1891), but the reports are either very incomplete, or else suggest adenocarcinoma or squamous carcinoma rather than anaplastic carcinoma of the oat-cell variety. Zadek (1933) published a coloured plate of a Romanowsky-stained smear of pleural fluid from a case of bronchial carcinoma, but the cells labelled "Endothelien ? Karzinomzellen" are almost certainly endothelial cells.

Quensel (1928a and b) examined a range of pleural and peritoneal effusions by a wet-chamber method, and published many beautiful photographs of exudate cells including tumour cells. Of 
five cases due to bronchial carcinoma, he found four with collections of vacuolated cells of the adenocarcinoma type, and one with large pleomorphic cells. There were no cases of oat-cell carcinoma.

Numerous workers have used the cell-block technique by which sections are made of the centrifuged deposit, but almost all of the published descriptions and illustrations of positive findings in bronchial carcinoma have shown the acinar formations of adenocarcinoma (Goldman, 1929 ; McDonald and Broders, 1939 ; Schlesinger, 1939 ; Wihman, 1948 ; Taylor and Thompson, 1949). In a few cases there have been malignant cells of squamous origin (Marcuse and Coulter, 1948), or of doubtful or indeterminate type (Eisenberg, Wallerstein, and Plato, 1933 ; Foot, 1937), and many others have given figures for "positives" and "negatives" without details; but the only acceptable report of oat-cells being found by this method is that of Wihman (1948), where the cells occurred in large aggregates.

Among those who have used wet-fixed smears (Dudgeon or Papanicolaou methods), only Bamforth (1946) has given descriptions and illustrations of the main varieties of malignant cells found in pleural effusions. Of 13 cases of bronchial carcinoma in which malignant cells were found, 12 showed cells of the adenocarcinoma type (which Bamforth calls "columnar") and one showed typical oat-cells of the same appearance as those found in sputum. He gives a drawing of these, apparently the first illustration in the literature of oat-cells in a pleural fluid smear.

It has even been questioned whether the oatcells of bronchial carcinoma are cytologically recognizable at all. Hauptmann (1948) made direct smears from tumours, using Romanowsky stains as well as Papanicolaou's method, and considered the oat-cells to be indistinguishable from lymphocytes.

In the course of systematic cytological examinations of pleural and peritoneal fluids, using a modified Widal technique, I have found that effusions complicating anaplastic oat-cell bronchial carcinoma do in fact often contain recognizable malignant cells of a hitherto undescribed type. Although they do not look malignant to an eye trained to expect large size, hyperchromasia, cytoplasmic basophilia, prominent nucleoli, and bizarre variations, they are none the less perfectly characteristic, and, once recognized, are not easily confused with any other type of cell. In particular, they bear no resemblance whatever to pleural endothelial cells (Figs. 1 and 2). The cases to be described illustrate this cell type, as well as the other less common but better known types found in effusions complicating adenocarcinoma and squamous carcinoma of the bronchus.

\section{Materials AND Methods}

Of the 21 cases to be described, 20 formed part of a series of 270 cases of pleural or peritoneal effusion, fluids from which were examined routinely in the clinical pathological laboratory of the Radcliffe Infirmary, Oxford. One further case (Case 21) is included because it was possible to compare the cells of sputum and pleural exudates. The sputum of the other 20 cases was not studied.

The 20 cases to be described from the series all showed clinical or histological as well as cytological evidence of primary bronchial carcinoma. There were a further 17 cases of pleural effusion considered to be due to primary bronchial carcinoma in which no malignant cells were found. These will not be considered further except that they are included in the Table.

All of the effusions except one were aspirated during life from the pleural cavity. In Case 6 the fluid was from the peritoneal cavity.

\section{Preparation of SMears}

Most textbooks of clinical pathology recommend the technique of Widal and Ravaut (1900) for making smears of serous fluids. Smears made by this method are slow to dry; the cells are shrunken, their nuclei appear pyknotic, and there is often background staining. We have used the following modification, which ensures the quick drying essential for good Romanowsky staining.

Fluid is collected into 1-oz. bottles containing $4 \mathrm{ml}$. of sterile $3.8 \%$ sodium citrate solution. The examination is carried out if possible on the day of collection.

About $10 \mathrm{ml}$. of the fluid is centrifuged until the white cells are deposited (five minutes at 1,500 r.p.m. is sufficient).

The supernatant fluid is poured off, and the tube is held upside down so that no fluid runs back on to the deposit.

A flamed metal loop is introduced into the tube from below, and a pinhead-sized portion of the deposit is removed. A loopful is too milich, even when it can be obtained.

The material removed should be of a creamy consistency. It is spread out rapidly on a slide with the loop, taking care that the loop does not go over the same place twice. The smear should dry instantaneously. If the deposit contains fibrin, the fragment may be more tenacious, and should be lightly drawn over the surface of several slides, one or two of which may be satisfactorily quick drying.

Smears made by this technique occupy only a small area of the slide, for example, $1 \mathrm{~cm} . \times 2 \mathrm{~cm}$., but the cells lie close to one another and many thousands can be rapidly examined.

The air-dried smears are stained exactly as for blood or marrow films. We have used the May-GrünwaldGiemsa combination, but Leishman's stain is also 
satisfactory. It is desirable to mount the film with a coverslip, so that it can be examined under a dry $4 \mathrm{~mm}$. objective and is protected from dust.

\section{Results}

Summaries of the 21 cases in which malignant cells were found are given in the Appendix. There were 37 cases in the consecutive series believed to have primary bronchial carcinoma. These are classified in the Appendix (see p. 32). Twenty (54\%) had effusions containing cells interpreted as malignant. In four cases $(1,2,3$, and 4$)$ these cells were similar to the adenocarcinoma cells which are most commonly seen in malignant peritonitis in carcinoma of ovarian or alimentary origin ; they occurred in clumps and showed marked vacuolation (Fig. 7). In Cases 1 and 2 there was postmortem or biopsy confirmation of adenocarcinoma. In one case (Case 5) subsequently proved to have a squamous type of bronchial carcinoma, the malignant cells were large, with profuse cytoplasm, and lay separate from one another (Fig. 8). In the remaining 15 cases, the malignant cells were of a type which I shall refer to as the oat-cell. This name is not given on account of any resemblance to oats, but because these cells correspond to the oat-cells of histological sections. This correspondence was demonstrated in eight cases; the remaining seven died without biopsy or necropsy.

\section{Description OF THE "OAT-CELl"}

The oat-cell is illustrated in Figs. 1, 2, 3, and 4.

In examining a Romanowsky-stained smear, oatcells are not prominent, since they are not very large, show little cytoplasmic basophilia, and seldom have distinct nucleoli ; they may also occur in very small numbers. They can be picked out by their comparatively pale-staining nuclei and scanty cytoplasm. Although isolated examples are seen, they commonly lie in small groups and occasionally in clumps which are identifiable in sections of hardened deposit. The cell diameter is usually about $15 \mu$, but there is variation from case to case, and also considerable variation in a single smear. In any group of these cells it is very common to see one or more very small cells, sometimes inserted between several large ones. Diameters above $30 \mu$ are hardly ever seen.

A very characteristic feature is the high ratio of nucleus to cytoplasm. Since the cells usually lie in small groups, the scarcity of cytoplasm produces an appearance of flattened adjacent nuclear borders, and the nuclei often appear like unequal pieces in a mosaic, polygonal in shape and separated by narrow clefts. Only in the case of iso- lated cells is a round or oval shape apparent, but $\underset{\vec{A}}{\vec{A}}$ even here the nuclear borders are generally irre- $\frac{9}{0}$ gular. In Case 21 there were frequent forms in which one (or sometimes two) spherical nuclei $\frac{\partial}{\omega}$ were partly surrounded by another crescentic $\vec{\nabla}$ nucleus in the same cell (Fig. 4).

The nucleus shows a rather fine chromatin pattern without any heavy areas or markings, but $\overrightarrow{0}$ parts of it usually show fine parallel strands and $\overrightarrow{-}$ there are ill-defined paler areas and fenestrations. $\vec{\omega}$ Nucleoli are not usually visible, but a few palely basophilic areas can sometimes be distinguished. $\vec{x}$

The cytoplasm exists as a thin basophilic rim. $\stackrel{\bullet}{0}$ It often appears of a rather smooth slate-blue or $\overrightarrow{\tilde{\sigma}}$ grey. A few very clear, punched-out vacuoles not ${ }^{\circ}$ exceeding $3 \mu$ in diameter are often scattered $\stackrel{\circ}{\triangle}$ in the cells, and characteristically involve the $\overrightarrow{-}$ nuclei as well as the cytoplasm : they are stained by Sudan black.

Cells of this type are not often seen in mitosis, $\stackrel{\Im}{\triangle}$ but in Case 16, where the cells were unusually of abundant, mitotic figures could be found without ${ }^{\AA}$ difficulty.

In Case 12 malignant cells were found showing more cytoplasm than is usual in anaplastic lung carcinoma. Post-mortem sections showed pleo-ڤ̊ morphic cells with relatively abundant cytoplasm. $\stackrel{\mathbb{\Omega}}{\Omega}$

The Table shows the cases of bronchial car- $\Rightarrow$ cinoma classified according to cytological and $\frac{0}{3}$ histological findings.

In one case (Case 21), which is not classified with the others since it was not part of the con secutive series, sputum was examined as well as pleural fluid. Oat cells were recognized in both, ָָ

TABLE

COMPARISON OF CYTOLOGICAL AND HISTOLOGICAL FINDINGS IN 37 CONSECUTIVE CASES OF BRONCHIAL CARCINOMA WITH MALIGNANT EFFUSION

\begin{tabular}{|c|c|c|c|c|c|}
\hline \multirow[b]{2}{*}{$\begin{array}{l}\text { Histological } \\
\text { Findings }\end{array}$} & \multicolumn{4}{|c|}{ Cytological Findings } & \multirow{2}{*}{ 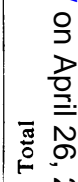 } \\
\hline & 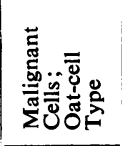 & 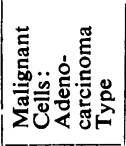 & 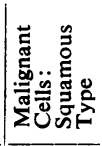 & 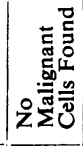 & \\
\hline $\begin{array}{l}\text { Anaplastic and oat- } \\
\text { cell carcinoma }\end{array}$ & $\begin{array}{c}7 \\
(\text { Cases 6- } \\
12)\end{array}$ & & & 2 & \\
\hline Adenocarcinoma & & $\begin{array}{c}1 \\
\text { (Case 2) }\end{array}$ & & & 18 \\
\hline $\begin{array}{l}\text { Mixed oat-cell and } \\
\text { adenocarcinoma }\end{array}$ & $\begin{array}{c}1 \\
\text { (Case 13) } \\
\end{array}$ & $\begin{array}{c}1 \\
\text { (Case 1) }\end{array}$ & & & $2 \stackrel{\mathbb{2}}{\stackrel{4}{+}}$ \\
\hline Squamous carcinoma & & & $\begin{array}{c}1 \\
\text { (Case 5) }\end{array}$ & 1 & 2 움 \\
\hline No biopsy or necropsy & $\begin{array}{c}7 \\
\text { (Cases 14 } \\
20)\end{array}$ & $\begin{array}{c}2 \\
\text { (Cases } 3 \\
\text { and 4) }\end{array}$ & & 14 & 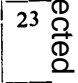 \\
\hline Total .. & 15 & 4 & 1 & 17 & 370 \\
\hline
\end{tabular}




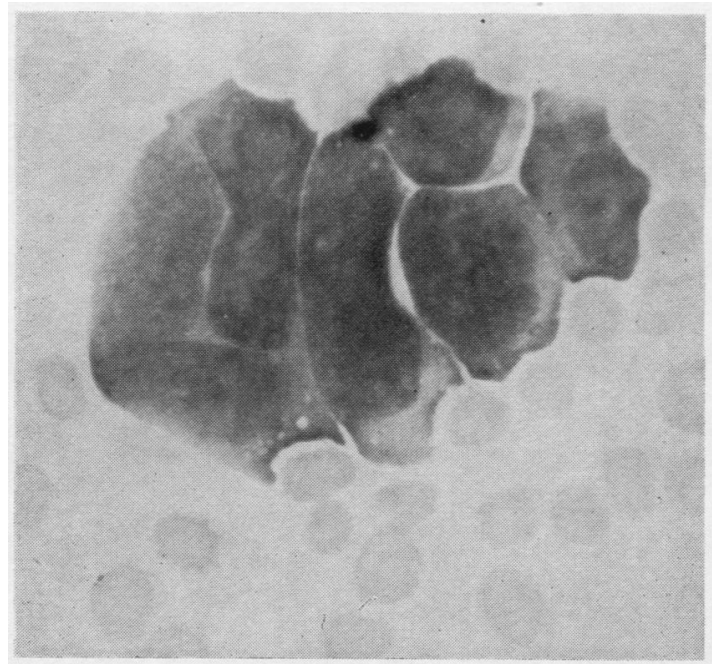

Fic. 1.-Case 19: Group of six oat-cells in pleural fluid. Their nuclei are mutually compressed, giving the "mosaic" effect. (May-Grünwald-Giemsa.) $\times 1160$.

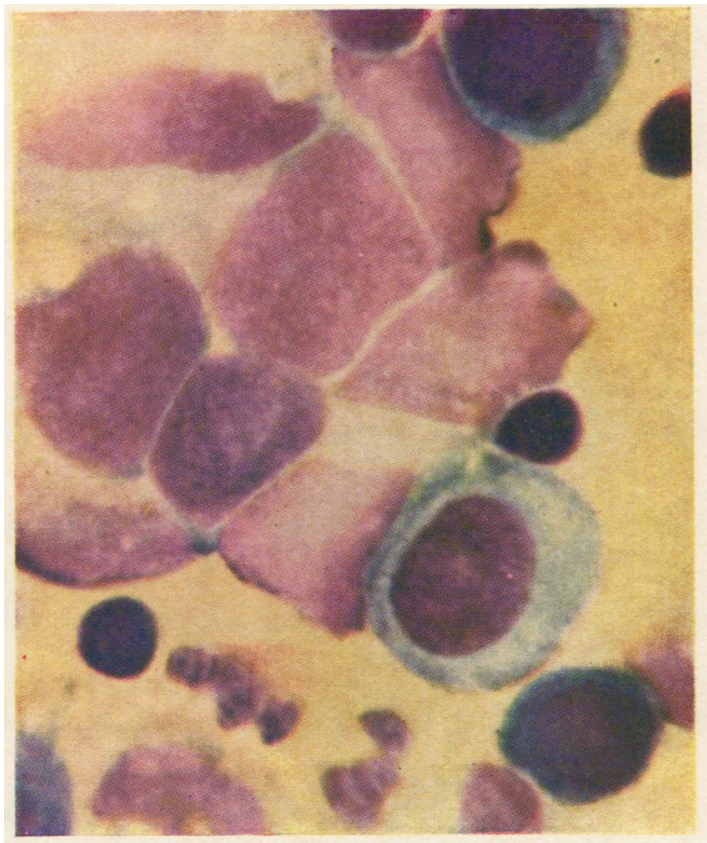

Fig. 2.-Case 19: Pleural fluid. Most of the field is taken up by a cluster of oat-cells. Eight nuclei of these cells are shown. Adherent to the lower right part of the cluster are an endothelial cell and a lymphocyte. Other endothelial cells, lymphocytes and polymorphs are shown in whole or in part. Note the darkstaining nuclei and basophilic cytoplasm of the endothelial cells, compared with the pale staining of the malignant cells. (Agfacolor photograph of May-Grünwald-Giemsa film.) $\times 1460$.

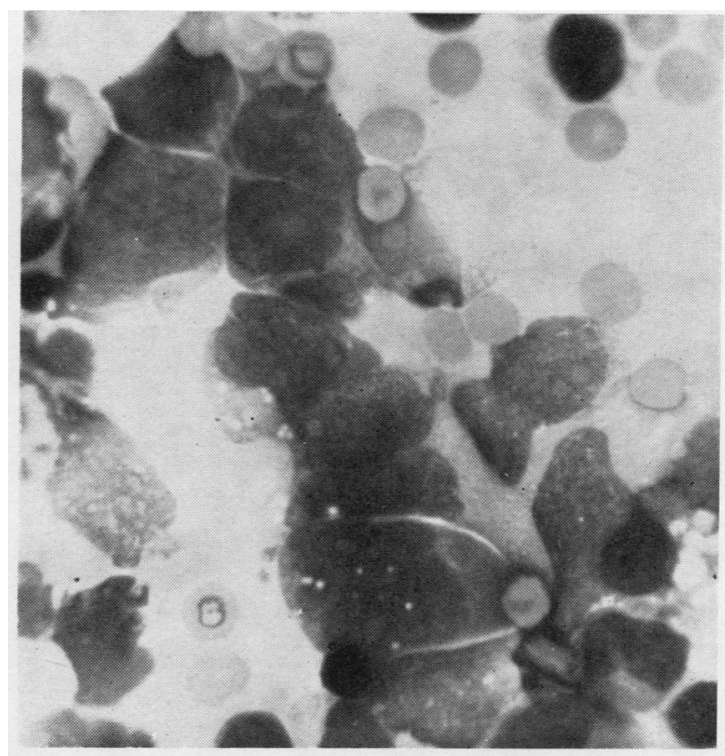

F10. 3.-Case 7: Pleural fluid. Almost all the nucleated cells in this field are "oat-cells." They are unusual in showing distinct nucleoli. Red cells and lymphocytes are also present. (MayGrünwald-Giemsa.) $\times 1160$.

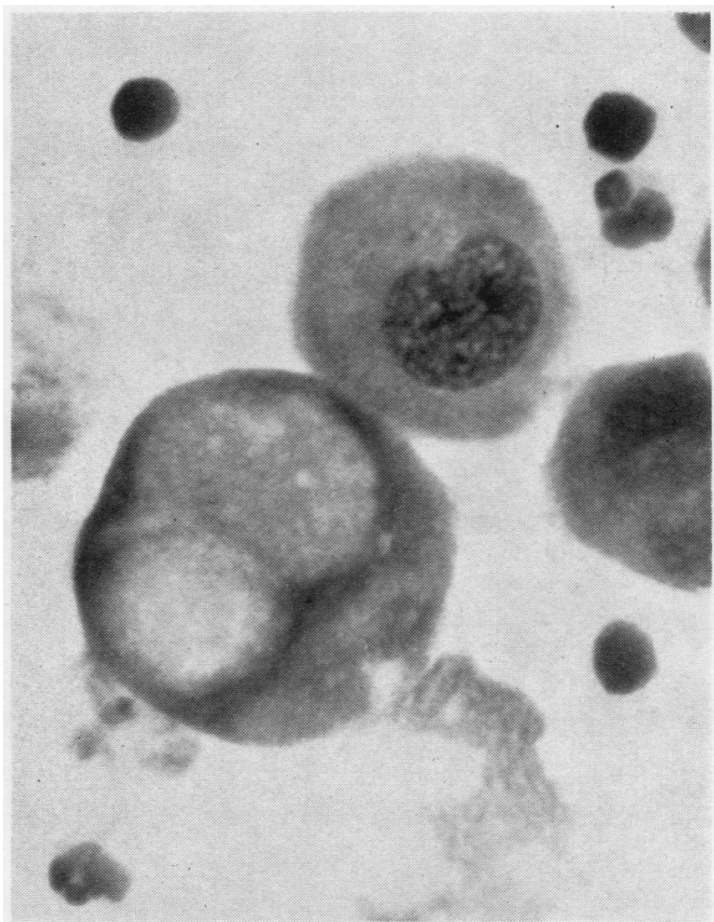

Fio. 4.-Case 21: Pleural fluid. Of the two central cells, the upper right is an endothelial cell; the lower left is an oat-cell showing two pale nuclei partly surrounded by a third crescentic one. (May-Grünwald-Giemsa.) $\times 1460$. 


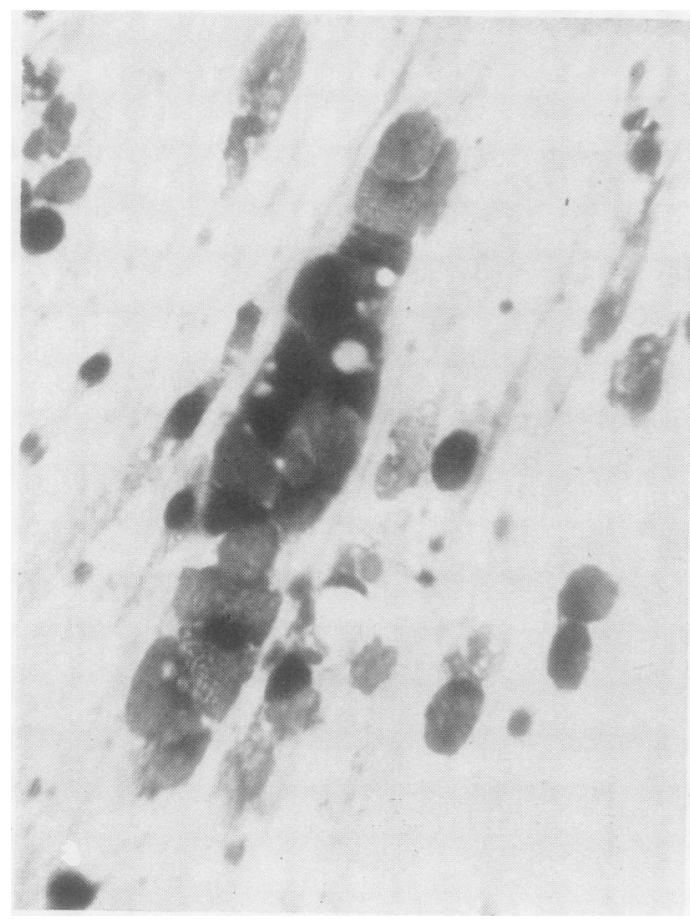

FIG. 5.-Case 21: Sputum. Air-dried film stained with MayGrünwald-Giemsa showing oat-cells. $: 550$.

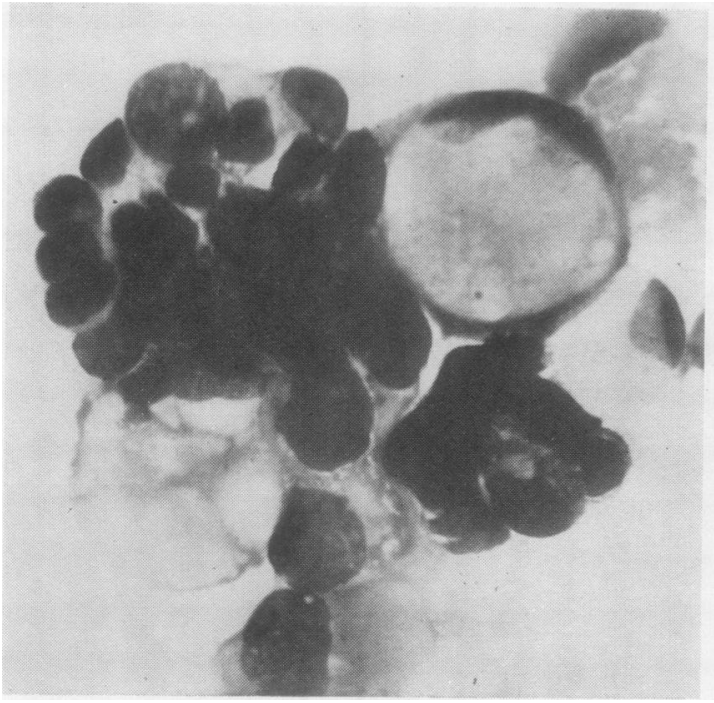

Fig. 7.-Case 4: Pleural fluid. All the cells shown are malignant cells of the adenocarcinoma type, separated from red cells by albumin flotation. (May-Grünwald-Giemsa.) $\times \mathbf{5 5 0}$.

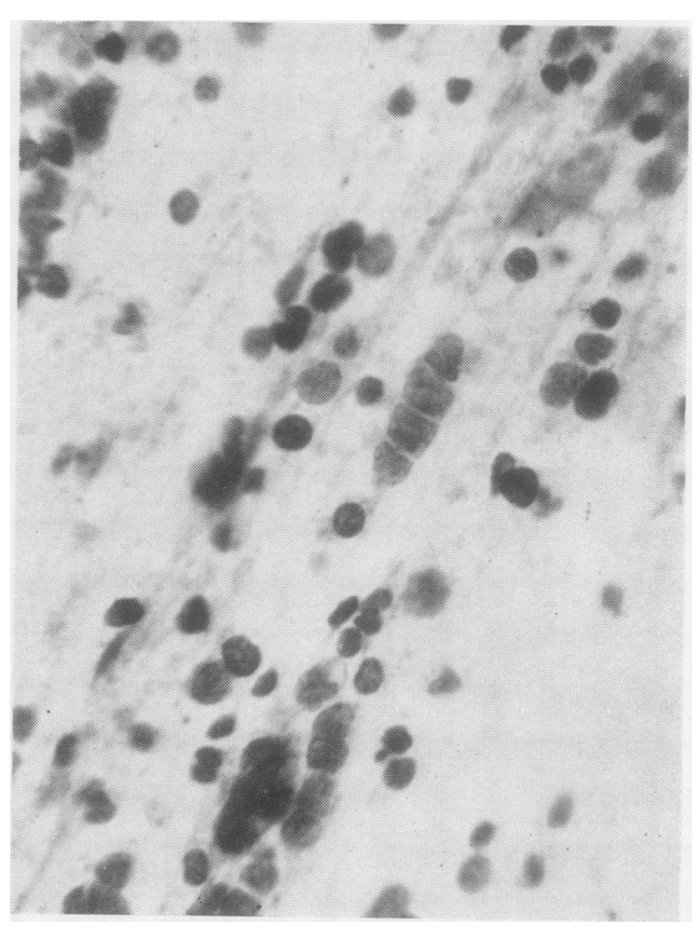

Fic. 6.-Case 21: Sputum. Papanicolaou-stained film, showing appearance of oat-cells by this method. The smaller size of the $\times 550$.
cells compared with Fig. 5 is due to the wet-fixation technique.

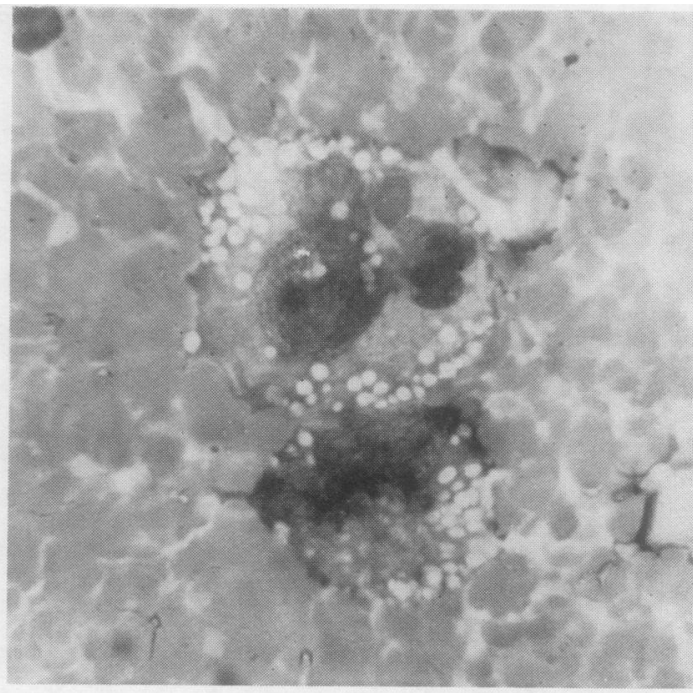

Fig. 8.-Case 5: Pleural fluid. The two central cells are malignan cells from a squamous carcinoma. (Direct film of a haemorrhagic fluid, stained May-Grünwald-Giemsa. $\times 1160$ 
and it was possible to compare the appearance of these cells in Papanicolaou preparations as well as in air-dried May-Grünwald-Giemsa stained films of the same sputum. By this means it could be shown that the oat-cells of pleural fluid, as seen by our technique, do in fact correspond with the oat-cells of Papanicolaou preparations (Figs. 5 and 6) as illustrated by the Vincent Memorial Laboratory, Boston (1950).

In the expectation that smears taken direct from fresh anaplastic bronchial carcinomas would present the same appearance when stained by our technique, I examined 11 lung tumours in this way within an hour of operative removal. Most of these were of squamous, large spheroidal, or glandular varieties, but two of them proved histologically to be typical oat-cell growths. Direct smears of material aspirated from these did not show the same appearance as the oat-cells of pleural fluid, the principal difference being the absence of mutual distortion of nuclei. This discrepancy is probably explained by the fact that these cells were torn from their setting, whereas the small metastases found in pleural fluid are seen entire, with their cytoplasm perfectly preserved. In the material aspirated from oat-cell tumours it is difficult to find a cell showing cytoplasm at all. I have to disagree with Hauptmann (1948), who found the cells of oat-cell carcinoma indistinguishable from lymphocytes; in the two growths which I have examined the oat-cells were larger, had an entirely different nuclear structure from that of lymphocytes, and usually lacked cytoplasm, while lymphocytes always preserve a cytoplasmic rim.

\section{Discussion}

Although primary carcinoma of the lung shows a considerable range of histological types, several of which may occur in one tumour, it appears that the metastases show more uniformity; the three well-recognized types, squamous, oat-cell, and adenosarcinoma, are quite distinct whether they are observed in sputum or in serous fluids.

SQuamous Carcinoma.-In the cytological examination of sputum, squamous carcinoma is perhaps the most commonly recognized variety, and adenocarcinoma the least. Where pleural fluid is concerned, on the other hand, squamous carcinoma cells are only rarely seen ; there is only one example in the present series (Case 5). The better-differentiated types do not easily metastasize to the pleura, and there appears to be no record in the literature of cornified cells being found in p'eural fluid. (The only two cases in which I have observed cornified cells in pleural fluid were both of ruptured oesophagus, and the cells concerned showed no evidence of malignancy.) In Case 5, the sole example in this series of a squamous carcinoma, the tumour was rather anaplastic and a diagnosis of the type could hardly have been made on cytological evidence alone ; the cells were isolated one from another, were large, and did not have the typical appearances either of the adenocarcinoma or of the oat-cell type (Fig. 8).

ADENOCARCINOMA.-The present series includes only four cases of adenocarcinoma thought to be primary in the lung with malignant cells in pleural fluid (Cases 1-4). Malignant acini are quite frequently seen in pleural fluid, but in many cases the involvement of the lung and pleura has been secondary to an adenocarcinoma elsewhere; wherever the growth arose the metastatic cells have the same characteristic features-aggregation in clumps, often of dozens or scores of cells (which in sections appear as rosettes or hollow acinar formations), together with a tendency to giant vacuolation. Very large and bizarre individual cells, usually with enlarged nucleoli, may occur in the same field with large clumps or spheres of regular, more or less uniform, cells which show no obvious malignant characteristics (Fig. 7). The four cases in this series do not show any features which have not been noticed by previous authors.

Oat-Cell Carcinoma.-From the frequent occurrence of oat-cell carcinoma and the scarcity of descriptions in the literature of the oat-cells in malignant effusions, one can only deduce that these cells are not being recognized when they occur. The cells which I have described in this paper as oat-cells have been seen only in certain cases of carcinoma of the lung, all of which are now dead from the disease (Cases 6-21), and in every case where there has been a biopsy or a necropsy the primary growth has been found to be of the oat-cell type. Apart from this evidence the cells are recognizably the same as those which have been previously described from the bone marrow in carcinomatosis secondary to bronchial carcinoma, and from bronchial secretions ; photographs have been published by Rohr and Hegglin (1936), Rohr (1949), and Delarue and Orcel (1952) showing the round or polygonal nuclei with mutual compression and the narrow cytoplasmic borders. Furthermore, in Case $21 \mathrm{I}$ have compared the malignant cells found in the sputum with those of the pleural fluid, and found a close correspondence of appearances in air-dried Romanowsky-stained films; at the same time the malignant cells shown in Papanicolaou preparations of the sputum were absolutely typical of the 
oat-cell type as figured by Bamforth (1946), Woolner and McDonald (1949), Vincent Memorial Laboratory, Boston (1950), and other authorities.

To a pathologist who is familiar with the benign cells of effusions, the oat-cells described above are sufficiently characteristic to allow of an unequivocal report of carcinoma even in cases where they lie separate from another and are present in small numbers. Since they occur most frequently in effusions complicating carcinoma of the lung, a provisional opinion of the primary site is justified; it was possible in Case 6 to suggest the lung as the primary site of the tumour from the examination of ascitic fluid. It is likely, however, that similar cells can arise in tumours of other sites; I have seen somewhat similar cells in an effusion due to a malignant synovioma, and the metastatic cells of sympathicoblastoma which are sometimes found in the bone-marrow are not very unlike the oat-cells of pleural fluid. There is scope for much more extensive inquiry into the cytological features of all types of malignant metastatic cells.

\section{SUMMARY}

Malignant cells have been identified in 21 cases of pleural and peritoneal effusion complicating primary carcinoma of the lung. In one case the cells were of squamous type, in four they were typical of adenocarcinoma, and in 15 they were of a type not previously described from Romanowsky-stained films of serous fluids. Evidence is presented for regarding these as the "oat-cells" of anaplastic bronchial carcinoma. In eight cases there was histological confirmation of oat-cell carcinoma ; the remaining seven died with a clinical diagnosis of primary carcinoma of the lung but were not subjected to necropsy.

I am grateful to Dr. A. H. T. Robb-Smith and to Dr. R. G. Macfarlane for their advice and help; also to Dr. J. C. Sherris for correcting the manuscript. My thanks are also due to all the colleagues who have sent material.

Bamforth, J. (1946). Thorax, 1, 118.

Bloch, M. (1905). Les néoplasmes malins primitifs de la plévre. Bloch, M. (1905).

Thesis, Paris.

Delarue, J., and Orcel, L. (1952). Sem. Hop. Paris, 28, 1014. 752.

Eisenberg, A. A., Wallerstein, H., and Plato, A. (1933). J. Lab. clin. Med., 19, 315.

Erben, F. (1906). Z. Heilk., 27 (abt. intern. Med.), 3.

Foot, N. C. (1937). Amer. J. Path., 13, 1.

Fraenkel, A. (1892). Berl. klin.Wschr., 29, 497, 534

Goldman, A. (1929). Arch. Surg., 19, 1672.

Houman, A. (1948). Amer. J. Path. 241199.

McDonald, J. R., and Broders, A. C. (1939). Arch. Path., Chicago, 27, 53.

Marcuse, P. M., and Coulter, W. W. (1948). Tex. St. J. Med., 43, 623.

Meslay and Lorrain (1903). Bull. Soc. anat. Paris, 78, 88.

Papanicolaou, G. N., and Traut, H. F. (1943). Diagnosis of Uterine Cancer by the Vaginal Smear. Commonwealth Fund, New York. Quensel, U. (1928a). Acta med. scand., 68, 458.

- (1928b). Ibid., Suppl. 23.
Quincke, H. (1882). Dtsch. Arch. klin. Med., 30, 580.

Ravaut, P. (1901). Le diagnostic de la nature des épanchements sérofibrineux de la plevre (cytodiagnostic). Thesis, Paris.

Rohr, K. (1949). Das menschliche Knochenmark, 2nd ed. Thieme Stuttgart.

and Hegglin, R. (1936), Dtsch. Arch. klin. Med., 179, 61

Schlesinger, M. J. (1939). Arch. Path., Chicago, 28, 283.

Schulze-Vellinghausen, A. (1900). Münch. med. Wschr., 47, 647. Q

Schwalbe, J. (1891). Dtsch. med. Wschr., 17, 1235.

Taylor, H. E., and Thompson, W. J. (1949). Canad. med. Ass. J., $61,413$.

Vincent Memoriai Practitioner, 74, 497. 1950). The Cytologic Diagnosis of Cancer, compiled by Graham, R. M., MacKinney, D. C., $\vec{\omega}$ Rheault, M. H., Soule, M. H., Rudolf, K. A., Gray, E., Burke, A., and Bradford, M. S. Saunders, Philadelphia and London.

Widal and Ravaut (1900). C.R. Soc. Biol. Paris, 52, 648.

Wihman, G. (1948). Acta med. scand., Suppl. 205.

Woolner, L. B., and McDonald, J. R. (1949). Surg. Gynec. Obstet., $88,273$.

Zadek, I. (1933). In Handbuch der allgemeinen Hämatologie, ed.Hirschfeld, H., and Hittmair, A. Vol. I, p. 1373. Urban and Schwarzenberg, Berlin.

\section{A P P E N D I X}

The following table summarizes 21 cases of malignant $\bar{Z}$ effusion complicating bronchial carcinoma, in which malignant cells were found in the fluid.

\begin{tabular}{|c|c|c|c|}
\hline ase & Sex & Age & Clinical and Pathological Description \\
\hline 1 & $\mathbf{M}$ & 48 & 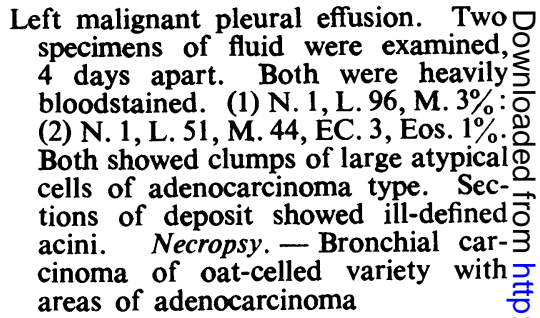 \\
\hline
\end{tabular}

2 M 54 Left malignant pleural effusion. Biopsy of nodule in chest wall showed adeno-으 carcinoma. Three specimens of fluid $\stackrel{\square}{x}$ were examined; all deeply blood- $\frac{x}{\sigma}$ stained, most of the white cells being $\frac{0}{3}$ lymphocytes. In addition there were clusters of malignant cells of adeno- $\subseteq$ carcinoma type

3 M 63 Clinically left bronchial carcinoma with 윽 malignant pleural effusion. The fluid $D$ was haemorrhagic; N. 13 , L. 79 , 을 M. 5, Eos. $3 \%$. There were collections of adenocarcinoma cells, often $\mathrm{N}$ much vacuolated; a few of the vacuoles gave a positive periodic acid- 0 Schiff stain following salivary diges- $N$ tion, indicating mucus secretion. Died without biopsy or necropsy

4 M 65 Clinical diagnosis left bronchial carcinoma with pleural effusion. The fluid was heavily blood-stained. N. 2 , L. 58, M. 10 , Eos. 29 , B. $1 \%$. There were collections of tumour cells of $\stackrel{+}{+}$ adenocarcinoma type, and sections of $\stackrel{\mathbb{Q}}{\Phi}$ fixed deposit showed a few malignant $\vec{\Phi}$ acini. Died without biopsy or necropsy

$\mathbf{N}=$ neutrophil, $L=$ lymphocyte, $\mathbf{M}=$ macrophage, $\mathbf{E C}=$ endothelial cell, Eos = eosinophil, $B=$ basophil, $P=$ plasma cell, $\mathbf{T C}=$ tumour cell. 

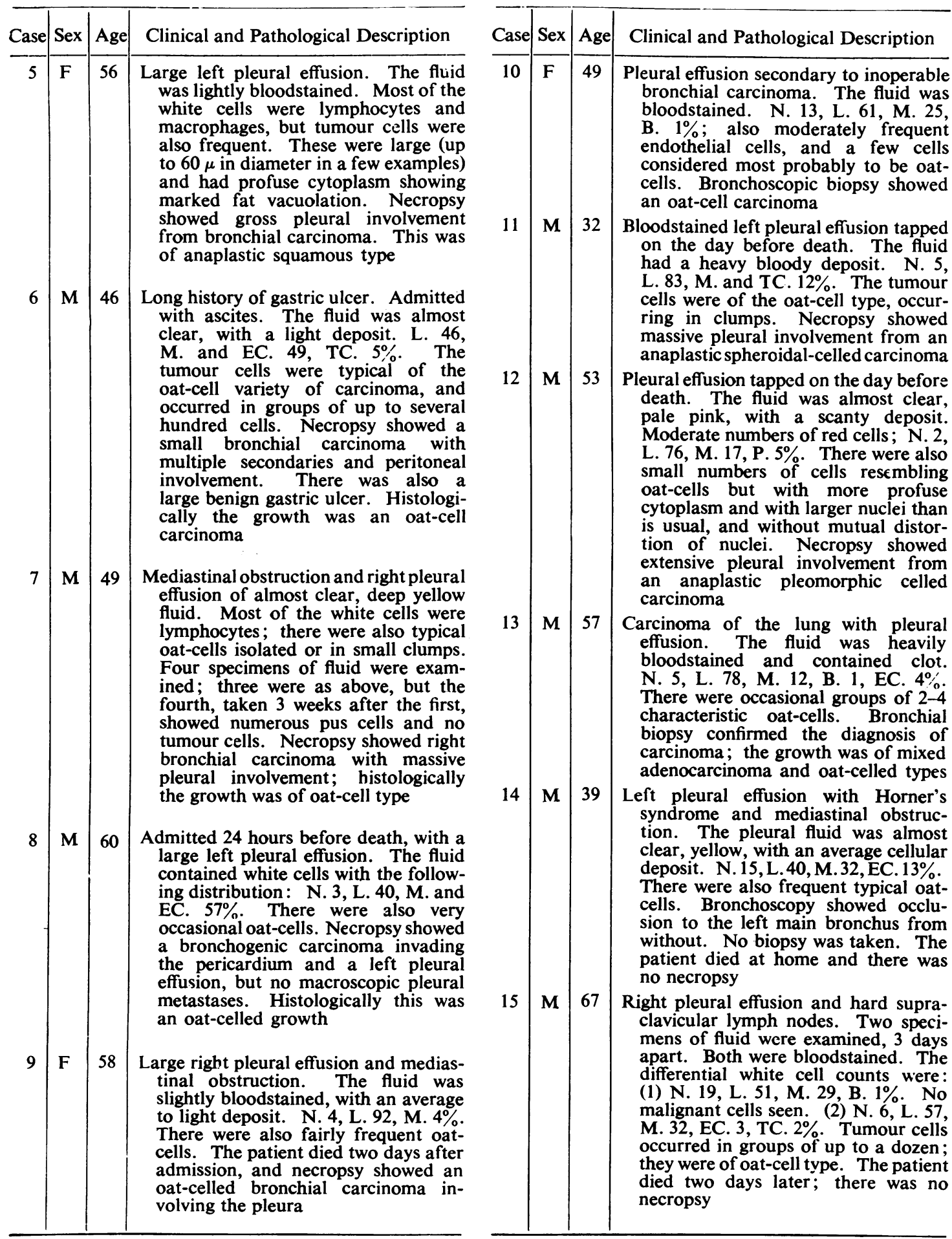


\begin{tabular}{|c|c|c|c|}
\hline Case & Sex & Age & Clinical and Pathological Description \\
\hline 16 & $\mathbf{M}$ & 55 & $\begin{array}{l}\text { Pleural effusion overlying a consolidated } \\
\text { area of lung. The fluid was slightly } \\
\text { bloodstained and there was a fairly } \\
\text { heavy cellular deposit. N. 1, L. 28, } \\
\text { M. 12, EC. 9, TC. } 48 \text {. Cells in mitosis } \\
2 \% \text {. The tumour cells occurred in } \\
\text { clumps, large enough to be identified } \\
\text { in sections of centrifuged deposit. } \\
\text { They were typical examples of oat- } \\
\text { cells. This patient died a few weeks } \\
\text { later and was registered as a case of } \\
\text { carcinoma of the lung. There was } \\
\text { no necropsy }\end{array}$ \\
\hline 17 & $\mathbf{M}$ & 63 & $\begin{array}{l}\text { Rccurrent right pleurisy of } 1 \text { year's } \\
\text { duration. Admitted with haemopty- } \\
\text { sis and right pleural effusion. While } \\
\text { in hospital he had a hemiplegic attack, } \\
\text { clinically thought to be due to cerebral } \\
\text { metastases from bronchial carcinoma. } \\
\text { Three specimens of the fluid were } \\
\text { examined. All were bloodstained and } \\
\text { showed a high proportion of lympho- } \\
\text { cytes; they also all contained oat- } \\
\text { cells in small numbers. The patient } \\
\text { died outside } 3 \text { months later, and no } \\
\text { necropsy was performed }\end{array}$ \\
\hline 18 & $\mathbf{M}$ & 65 & $\begin{array}{l}\text { Haemoptysis, right laryngeal palsy and } \\
\text { right pleural effusion. Hard lymph } \\
\text { nodes in the right side of the neck and } \\
\text { the right axilla. Two specimens of } \\
\text { fluid were examined } 2 \text { days apart. } \\
\text { (1) N. } 10, \mathrm{~L} .84, \mathrm{M} \text {. } 2 \text {, EC. } 3, \mathrm{P} .1 \% \\
\text { and occasional cells suggestive of } \\
\text { malignancy. (2) N. 12, L. 85, M. and } \\
\text { EC. } 3 \% \text { and moderate numbers of } \\
\text { tumour cells of oat-cell type. Death } \\
\text { occurred at home soon after discharge, } \\
\text { and there was no necropsy }\end{array}$ \\
\hline
\end{tabular}

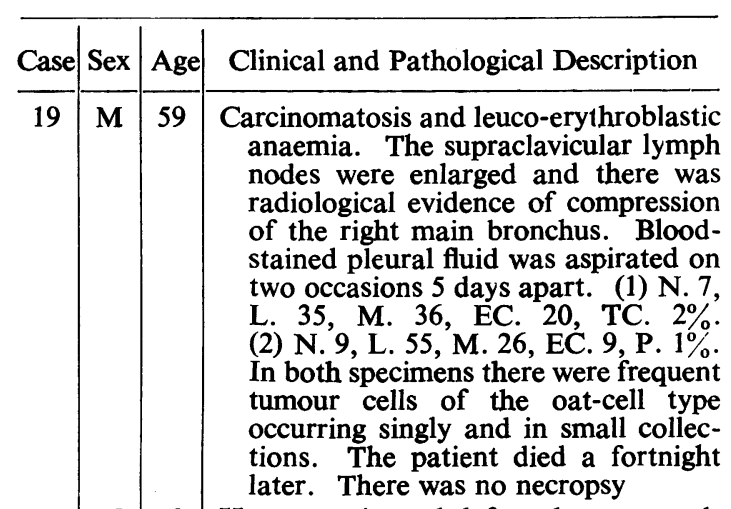

20

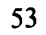

Haemoptysis and left pulmonary collapse with overlying pleural eflusion. Bronchoscopy showed a carcinoma of the left main bronchus, but no biopsy was taken. The fluid was slightly turbid. L. 93, M. 7\%; less than $1 \%$ of neutrophils, plasma cells, and endothelial cells. There were also frequent oat-cells lying singly and in groups. The patient died 6 months later. There was no necropsy

21 M 43 Right pleural effusion with hilar enlargements, a palpable mass in the liver, and a collapsed 12th thoracic vertebra. Clinically a case of inoperable carcinoma of the bronchus with metastases. The pleural effusion was aspirated 4 times, and 3 of the specimens were examined cytologically. (1) (right base) N. 35, L. 29, Eos. 1, EC. 35. Frequent oat-cells present. (2) (right interlobar) N. 26, L. 62, EC. 12. Frequent oat-cells present. (3) (right base) Similar to previous findings. The patient died a month later at home. There was no necropsy $\mathbf{N}=$ neutrophil, $\mathbf{L}=$ lymphocyte, $\mathbf{M}=$ macrophage, $\mathbf{E C}=$ endothelial
cell, Eos = eosinophil, $\mathrm{B}=$ basophil, $\mathbf{P}=$ plasma cell, $\mathbf{T C}=$ tumour cell. 